\title{
Human CD8 T cells generated in vitro from hematopoietic stem cells are functionally mature
}

\author{
Génève Awong ${ }^{1}$, Elaine Herer ${ }^{2}$, Ross N La Motte-Mohs ${ }^{1}$ and Juan Carlos Zúñiga-Pflücker ${ }^{1 *}$
}

\begin{abstract}
Background: T cell development occurs within the highly specialized thymus. Cytotoxic CD8 T cells are critical in adaptive immunity by targeting virally infected or tumor cells. In this study, we addressed whether functional CD8 T cells can be generated fully in vitro using human umbilical cord blood (UCB) hematopoietic stem cells (HSCs) in coculture with OP9-DL1 cells.

Results: HSC/OP9-DL1 cocultures supported the differentiation of CD8 T cells, which were TCR/CD $3^{\text {hi }} C D 27^{\text {hi }}$ $\mathrm{CD}_{1} \mathrm{a}^{\text {neg }}$ and thus phenotypically resembled mature functional CD8 single positive thymocytes. These in vitrogenerated T cells also appeared to be conventional CD8 cells, as they expressed high levels of Eomes and low levels of Plzf, albeit not identical to ex vivo UCB CD8 T cells. Consistent with the phenotypic and molecular characterization, upon TCR-stimulation, in vitro-generated CD8 T cells proliferated, expressed activation markers (MHC-II, CD25, CD38), secreted IFN- $\gamma$ and expressed Granzyme B, a cytotoxic T-cell effector molecule.

Conclusion: Taken together, the ability to direct human hematopoietic stem cell or T-progenitor cells towards a mature functional phenotype raises the possibility of establishing cell-based treatments for T-immunodeficiencies by rapidly restoring CD8 effector function, thereby mitigating the risks associated with opportunistic infections.
\end{abstract}

\section{Background}

T lymphocytes develop within the thymus, undergoing distinct differentiation events based on phenotype, while following spatial-temporal cues. The most immature human thymocytes are triple negative for CD3, CD4 and CD8, but express CD34. CD7 is one of the earliest markers to be expressed during human $\mathrm{T}$ cell ontogeny, followed by the upregulation of $\mathrm{CD} 1 \mathrm{a}$, which marks $\mathrm{T}$ cell commitment. Following this stage, human thymocytes progress to a CD4 immature single positive (CD4ISP) stage, at which point CD4 is expressed in the absence of CD8. Thereafter, a subset of CD4ISP cells are thought to complete TCR $\beta$ rearrangement leading to $\beta$-selection and differentiation to the $\mathrm{CD} 4^{+} \mathrm{CD}^{+}$double positive (DP) stage. Finally, following successful TCR $\alpha$ rearrangement, TCR $\alpha \beta$ expressing DP thymocytes undergo positive and negative selection events, which result in the production of $\mathrm{CD}_{4}^{+} \mathrm{CD} 8^{-}$and $\mathrm{CD} 4^{-} \mathrm{CD} 8^{+}$

\footnotetext{
* Correspondence: jczp@sri.utoronto.ca

'Department of Immunology, University of Toronto, and Sunnybrook Research Institute, 2075 Bayview Avenue, Toronto, Ontario M4N 3M5, Canada

Full list of author information is available at the end of the article
}

single positive (SP) T cells, which then emigrate to the periphery [1].

Cytotoxic CD8 SP T cells play a critical role in adaptive immunity by destroying virally infected or malignant cells. Cytoablative regimens to treat malignancies or HIV infection results in the destruction of $\mathrm{T}$ cells, leading to a period of immunodeficiency and a concomitant increase in opportunistic infections [2]. While hematopoietic stem cell (HSC) transplants can reconstitute the entire immune system, $\mathrm{T}$ cells are the slowest population to recover or may never recover at all $[3,4]$. The robust differentiation of multiple sources of HSCs [5-9] into T-progenitors using the OP9-DL1 coculture system suggests that these progenitor cells could be harvested in vitro to rapidly restore the $T$ cell compartment in vivo and thereby reduce the incidence of opportunistic infection and ultimately improve therapeutic outcomes [10]. While we have demonstrated that specific populations of T-progenitor cells generated in vitro can reconstitute the thymus of immunodeficient mice and generate CD8 single positive (SP) T cells in vivo [8], it was not clear whether functional maturation of mature CD8 $\mathrm{T}$ cells could take place entirely in vitro starting
Ciomed Central

() 2011 Awong et al; licensee BioMed Central Ltd. This is an Open Access article distributed under the terms of the Creative Commons Attribution License (http://creativecommons.org/licenses/by/2.0), which permits unrestricted use, distribution, and reproduction in any medium, provided the original work is properly cited. 
from umbilical cord blood (UCB) HSCs in OP9-DL1 cell cocultures.

Mature CD8 T cells were recently reported to be generated following coculture of early thymocyte progenitors (ETPs) on OP9-DL1 monolayers [11]. The absence of a clinically viable source from which to isolate low frequency ETPs, makes it difficult to envision a therapeutic approach to treat $\mathrm{T}$-immunodeficiency based on harvested postnatal thymocytes (PNT). Therefore, it is important to determine whether accessible sources of HSCs, such as umbilical cord blood, directed to differentiate in vitro can generate functionally mature CD8 $\mathrm{T}$ cells. Two elegant studies have reported the generation of cytotoxic human T cells from HSCs genetically modified to express tumor-specific TCRs cocultured with OP9-DL1 stromal cells $[12,13]$. Whether in vitrogenerated CD8 $\mathrm{T}$ cells derived from unmanipulated HSCs could also give rise to mature functional $\mathrm{T}$ cells and respond to signals delivered through an endogenously generated TCR remained to be tested. Here we demonstrate that long-term coculture of non-transduced human UCB HSCs on OP9-DL1 cells generates $\alpha \beta$ $\mathrm{TCR} / \mathrm{CD}^{+}{ }^{+} \mathrm{CD}^{+}{ }^{+} \mathrm{SP} \mathrm{T}$ cells that exhibit the molecular and cellular signatures corresponding to functionally mature $\mathrm{T}$ cells.

\section{Results}

Phenotypic characterization of human CD8 SP T-cells derived from HSCs cultured with OP9-DL1 cells

We have previously reported the ability to generate CD4 ${ }^{+} \mathrm{CD}^{+}{ }^{+} \mathrm{T}$-lineage cells as well as CD4 and CD8 single positive (SP) cells from human cord blood-derived $\mathrm{CD}^{+} 4^{+} \mathrm{CD}^{-/ 8^{-/ \text {low }}} \mathrm{HSC} / \mathrm{OP} 9-\mathrm{DL} 1$ cocultures [7], however the maturational, molecular and functional status of these CD8 SP T-cells were not assessed.
To address this, we analyzed long-term cocultures that were allowed to differentiate for an extended period of time. Figure 1 shows the presence of both DP and SP subsets from a day 65 coculture. Examination of multiple cocultures demonstrated the generation of CD8 SP $\mathrm{T}$ cells $(5.3 \% \pm 1.2 \%($ mean $\pm \mathrm{SE}, \mathrm{n}=6)$ ) after $60-70$ days of culture. Additionally, Table 1 displays an analysis for the number of CD8 T cells obtained from individual OP9-DL1 cultures initiated with different numbers of HSCs, which provides an indication of the expected CD8 SP cell yields per input HSC. We further examined the CD8 SP subset present in these cultures for the expression of cell surface markers CD3 and CD27 $[14,15]$, typically expressed on mature T-cells. Amongst the SP CD8 cells (SP8s) found in late cocultures, about $50-60 \%$ (Figures 1 for $50 \%$ and Figures 3 a for $60 \%$ ) expressed CD3/ $\alpha \beta$ TCR. Of note, the majority $(57 \% \pm$ $10 \%, \mathrm{n}=3$ ) of $\mathrm{CD}^{+} \mathrm{SP} 8 \mathrm{~s}$ were found to co-express CD27. In addition, $\mathrm{CD} 27^{+} \mathrm{CD} 3^{+} \mathrm{CD} 8^{+}$SPs were also found to lack CD1a expression, which is indicative of functional maturity [16]. This is in contrast to the subset of $\mathrm{CD}_{2} 7^{-} \mathrm{CD}^{+} \mathrm{CD}^{+}$SPs that continued to express $\mathrm{CD} 1 \mathrm{a}$, which is characteristic of the preceding stage in $\mathrm{T}$-cell differentiation [16] and consistent with reports showing that the acquisition of functional maturity by $\mathrm{CD}^{+}$thymocytes following positive selection is associated with the expression of CD27 and down-regulation of CD1a expression $[15,16]$.

\section{Molecular analysis of in vitro derived human CD8 SP T-cells from UCB HSCs}

To gain further insight into the phenotypically characterized CD8 SP T cells derived in vitro, we examined the expression of genes known to influence the differentiation or effector status of CD8 $\mathrm{T}$ cells by quantitative

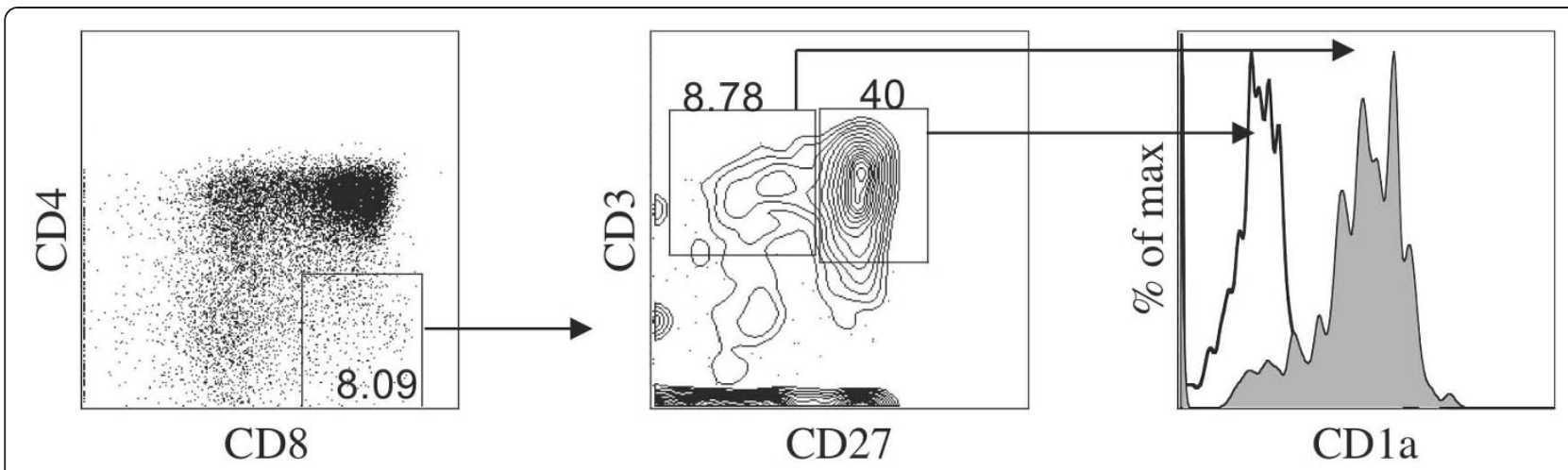

Figure 1 Characterization of $\mathrm{CD}^{+} \mathbf{T}^{\mathbf{T}}$ cells generated in vitro. Flow cytometric analysis for the expression of CD8 and CD4 from human UCBderived HSCs cultured on OP9-DL1 cells for 65 days. $C D 8^{+}$CD4 single positive (SP) cells were gated, as indicated, and analyzed for the expression of CD27 and CD3, with CD1a expression shown for cells gated as CD3 ${ }^{+}$CD27 or CD27 (shaded and clear histograms, respectively). Data are representative of over 6 experiments for CD8/CD4 expression and of 3 experiments for CD27/CD1a expression. 
Table 1 Generation of $\mathrm{TCR} / \mathrm{CD}^{+}{ }^{+} \mathrm{CD}^{+}$cells from $\mathrm{CD} 34^{+}$ CD38-/low hematopoietic progenitors in OP9-DL1 cocultures

\begin{tabular}{|c|c|c|}
\hline Experiment & $\mathrm{CD}^{2} 4^{+} \mathrm{CD} 38^{-/ \text {low }}\left(\times 10^{5}\right)$ & $\mathrm{TCR} / \mathrm{CD}^{+} \mathrm{CD}^{+}\left(\times 10^{5}\right)^{\mathrm{a}}$ \\
\hline 1 & 3.0 & 0.1 \\
\hline 2 & 8.0 & 7.0 \\
\hline 3 & 5.0 & 3.0 \\
\hline 4 & 8.0 & 3.0 \\
\hline 5 & 1.5 & 0.4 \\
\hline 6 & 0.3 & 0.35 \\
\hline
\end{tabular}

${ }^{a}$ Indicates the number of $\mathrm{TCR} / \mathrm{CD}^{+}{ }^{+} \mathrm{CD}^{+} \mathrm{T}$ cells obtained after flow cytometric sort purification from day 60-70 cocultures, which were seeded with the indicated number of $\mathrm{CD} 34^{+} \mathrm{CD} 38^{-/ \text {low }}$ cells.

real-time PCR. We examined the expression of Th-POK (Zbtb7b), Eomes, PLZF (Zbtb16) and Gata-3 transcript levels in SP8 $\mathrm{T}$ cells obtained from CD34 ${ }^{+} \mathrm{CD} 38^{-/ \text {low }}$ HSCs cocultured with OP9-DL1 cells for approximately 60-70 days. $\mathrm{CD}^{+} \mathrm{CD}^{-} \mathrm{CD}^{+}\left(\mathrm{Lin}^{+} \mathrm{SP} 4\right), \mathrm{CD} 4^{-} \mathrm{CD} 8^{+}$ $\mathrm{CD}^{+}\left(\mathrm{Lin}^{+} \mathrm{SP} 8\right) \mathrm{T}$ cells and $\mathrm{CD}^{+} 3^{+}$myeloid cells obtained from the mature lineage-positive fraction of UCB were used as controls. Consistent with the role of the zinc finger transcription factor Th-POK in CD4 lineage-commitment [17], Th-POK transcripts were barely detectable in coculture-derived SP8 T cells compared to $\mathrm{Lin}^{+}$SP4 T cells (Figure 2). Also, a low, but detectable, level of Th-POK expression was observed in UCB-ex vivo $\mathrm{Lin}^{+} \mathrm{SP} 8 \mathrm{~T}$ cells. In contrast, the T-box transcription factor Eomes, which is a critical regulator for CD8 $\mathrm{T}$ cell differentiation and effector function [18], was highly expressed in coculture-derived SP8 T cells at levels that were lower but comparable to that of peripheral SP8 $\mathrm{T}$ cells obtained from $\mathrm{Lin}^{+} \mathrm{UCB}$. Interestingly, we also observed a high level of this transcription factor in UCB-derived CD4 T cells, which is consistent with a recent report showing the expression of Eomes in a subset of naïve peripheral CD4 T cells [19]. In addition, the NKT cell/innate T cell transcription factor PLZF [20] was expressed at low levels in HSC/OP9-DL1 coculturederived CD8 T cells similar to UCB CD8 peripheral $\mathrm{T}$ cells. Lastly, we observed high levels of Gata-3 transcripts in coculture-derived SP8 T cells, likely owing to the Delta-like-induced signaling of Notch in these cells.

\section{Generation of functional human CD8 T cells from HSCs cultured with OP9-DL1 cells}

To address the functional status of in vitro-generated SP8s, we sorted the CD3/TCR-expressing subset (Figure $3 \mathrm{~A}$ ) and examined whether these cells had the capacity to up/down-regulate downstream differentiation markers, proliferate, express cytolytic effector-function molecules, and secrete $\gamma$-interferon (IFN $\gamma$ ) following stimulation with immobilized anti-CD3/anti-CD28
mAbs for 5 days. As shown in Figure 3B, a blast-like appearance based on Forward-light Scatter (FSC) is seen in stimulated (Stim) cells as compared to non-stimulated (NS) cells, which displayed significantly different $(p=$ $0.004)$ FSC mean values when analyzed over multiple experiments (NS, $460 \pm 12$; Stim, $524 \pm 10$ ). Additionally, stimulated cells up-regulated CD45RO, CD38 and MHCclass II expression, and down-regulated CD27 expression, as compared to non-stimulated cells (Figure 3C). As shown in Figure 3D, a similar trend was observed when $\mathrm{UCB}$ ex vivo CD8 T cells were assayed. However, a more prominent upregulation of $\mathrm{CD} 45 \mathrm{RO}$ and $\mathrm{CD} 38$, and less prominent downregulation of CD27, was observed. Nevertheless, further analysis of CD45RO MFI and the percentage of CD27 expression (Figure 3E) demonstrated a significant difference between non-stimulated and stimulated in vitro-derived CD8 $\mathrm{T}$ cells. Indeed, this was also observed for UCB-ex vivo CD8 T cells (Figure 3F).

Furthermore, to address the extent of cellular proliferation induced by TCR-stimulation, sorted $\mathrm{CD}^{+} \mathrm{CD}^{+}$ $\mathrm{T}$-cells were loaded with CFSE and incubated for 5 days with or without TCR-stimulation. Figure 4A shows that stimulated cells undergo many rounds of cell division as indicated by the loss of CFSE (left side) compared to non-stimulated cells and by the increase in cellularity (lower right-side). A similar loss of CFSE and increased cellularity was observed in UCB-ex vivo $\mathrm{T}$ cells (Figure $4 \mathrm{~B}$, left-side and lower right-side). Like UCB-ex vivo $\mathrm{CD} 8 \mathrm{~T}$ cells, we observed that in vitro-derived proliferating cells also displayed marked up-regulation of CD25 expression (Figure 4A and 4B, left side). The average percentage of CD25 on the cell surface of stimulated cells was $78 \% \pm 5 \%$, which was significantly higher than on non-stimulated cells (Figure 4A, upper right-side).

To determine whether these TCR-responsive in vitroderived CD8 SP T-lineage cells can be induced to express cytotoxic/effector-function molecules, the expression of Granzyme-B and IFN $\gamma$ were assessed. Intracellular Granzyme-B expression was detected in approximately $38 \%$ of stimulated $\mathrm{CD}^{+}{ }^{+} \mathrm{CD}^{+}{ }^{+} \mathrm{T}$-cells, as compared to non-stimulated cells that expressed much lower levels of Granzyme-B (Figure 4C). As demonstrated in Figure 4D, when in vitro-derived CD8 T cells were gated on Granzyme- $\mathrm{B}^{+}$cells, these corresponded to $\mathrm{CD} 25^{+}$proliferating cells. Finally, supernatants from wells containing in vitro-generated CD8 SPs were analyzed for the presence of IFN $\gamma$ following stimulation. As shown in Figure 4E, supernatants from cells stimulated with either $2 \mu \mathrm{g} / \mathrm{mL}$ or $10 \mu \mathrm{g} / \mathrm{mL}$ of anti-CD3/antiCD28 mAbs showed a significant increase in the amount of IFN $\gamma$, as compared to non-stimulated cells. In a separate set of experiments (Figure 4F), in vitroderived and UCB-ex vivo CD8 T cells were directly compared, and showed similar levels of IFN $\gamma$ production 

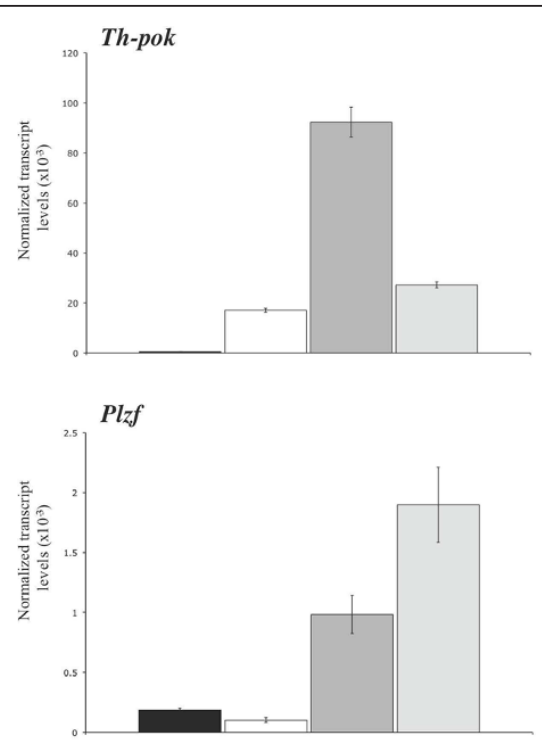
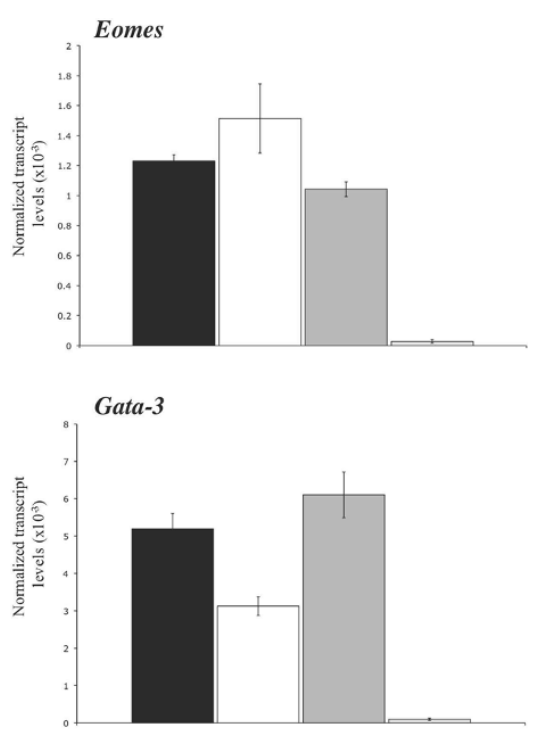

HSC/OP9-DL1-derived $\mathrm{CD}^{+}{ }^{+} \mathrm{CD} 4 \cdot \mathrm{CD} 8$

Ex vivo $\mathrm{UCB} \mathrm{CD}^{+} \mathrm{CD} 4 \cdot \mathrm{CD}^{+}$

Ex vivo $\mathrm{UCB} \mathrm{CD}^{+}{ }^{+} \mathrm{CD} 4^{+} \mathrm{CD} 8$ -

Ex vivo UCB $\mathrm{CD}^{+} 3^{+}$

Figure 2 Gene expression analysis of $\mathrm{CD}^{+}$SP T cells obtained from HSCs cultured on OP9-DL1 cells. Gene expression analysis by QRTPCR from coculture-derived CD8 SP T cells $\left(C D 8^{+}\right.$CD4 $4^{-}$CD3 $\left.3^{+}\right)$. CD8 SP, CD4 SP T cells and CD33 $3^{+}$myeloid cells were purified from the Lin ${ }^{+}$ fraction of UCB samples and served as controls. Transcript levels for the indicated genes were normalized to human $\beta$-actin, and these data are representative of 3 independent experiments, with the standard error bars shown corresponding to values obtained from triplicate wells within an individual experiment.

after TCR/CD28 stimulation. Taken together, these results show that in vitro-derived CD8 SP $\mathrm{T}$ cells are functionally mature.

Lastly, we also noted the appearance of $\mathrm{CD}^{+} \mathrm{CD}^{+}$ T-cells (Figure 1A and 3A), which could be selected by human MHC class II-expressing cells, which may be a $\mathrm{T}$-lineage cell or a non $\mathrm{T}$-lineage cell such as a dendritic cell. Indeed, when late day cultures were analyzed for the presence of MHC class II expressing cells, $\mathrm{MHC}-\mathrm{II}^{+}$ $\mathrm{CD} 34^{+} \mathrm{CD}^{+}$progenitor $\mathrm{T}$ cells and $\mathrm{MHC}-\mathrm{II}^{+} \mathrm{CD}^{-}$ non-T-lineage cells were detected as shown in Figure $5 \mathrm{~A}$. Figure 5B, demonstrates the generation of $\mathrm{CD}_{3}{ }^{+}$ $\mathrm{CD}^{-}$myeloid cells, which could provide MHC-II molecules to developing $\mathrm{T}$ cells. Interestingly, in contrast to the CD8 SPs, in vitro-generated CD4 SP T cells do not show the hallmarks of being functionally mature $\mathrm{T}$-cells. Experiments examining their proliferative ability revealed a lack of responsiveness to CD3 stimulation (data not shown). Also confirming these findings was the lack of CD27 expression on CD4 SP T-lineage cells compared to CD8 $\mathrm{T}$ cells in the same culture (Figure 6). Since this molecule is upregulated upon positive selection and present on mature naive $\mathrm{T}$ cells, the CD4 SP generated in these cultures may represent transitional cells that require additional differentiation signals that are not readily available in these cultures.

\section{Discussion}

The HSC/OP9-DL1 cocultures not only serve to characterize progenitor function or early events in human T-cell development [8], but may also provide a simple method for the generation of functional human T-cells in vitro. This approach may be applicable to cell-based immunotherapies that presently capitalize on $\mathrm{T}$-cell effector-function to induce/enhance anti-tumor eradicating immunity [21]. Thus far, adoptive cell transfer (ACT) for tumor eradication has employed the use of autologous and allogeneic $\mathrm{T}$ cells obtained from blood or tumor-infiltrating lymphocytes, followed by expansion protocols to generate millions of cells, with the efficacy of ACT depending on the ability to generate large cell numbers of $\mathrm{T}$ cells that maintain effector function. One caveat to stromal-based cultures of HSCs into CD8 $\mathrm{T}$ cells is that clinically relevant numbers of $\mathrm{CD} 8^{+}$ $\mathrm{T}$ cells are not readily obtained (Table 1 ) following one round of TCR-stimulation. However, one could attempt to overcome this by promoting expansion of CD8 $\mathrm{T}$ cells with artificial-APCs and cytokines with several rounds of stimulation [22,23]. Additionally, the number of CD8 T cells obtained in these cultures is directly related to the number of input HSCs; thus, expansion of HSCs prior to differentiation into $\mathrm{CD}^{+} \mathrm{T}$ cells would provide another strategy for the large-scale generation 
A

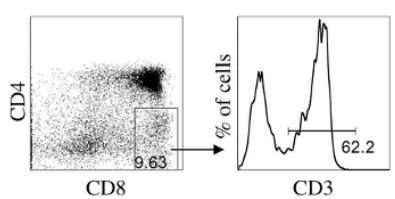

C

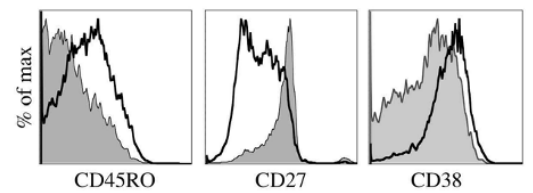

D

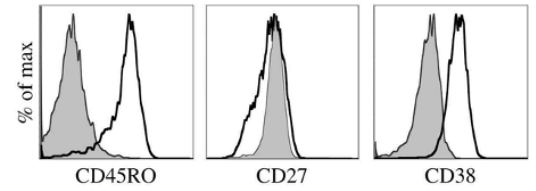

B
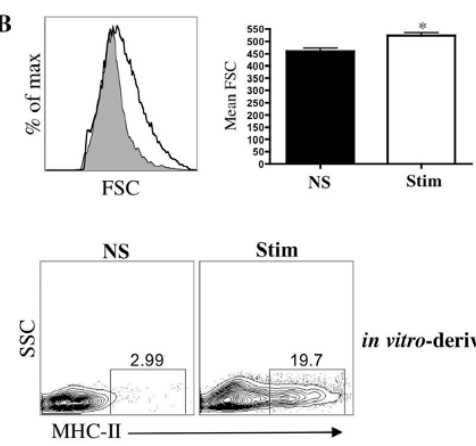

in vitro-derived CD8 $\mathrm{T}$ cells

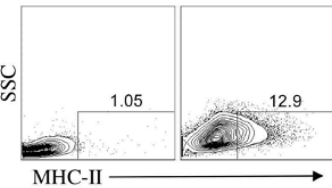

UCB-ex vivo CD8 T cells
E

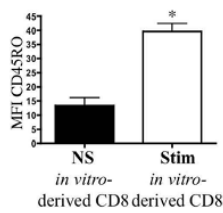

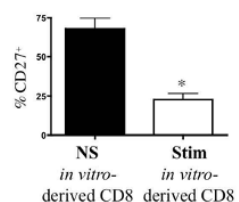

F
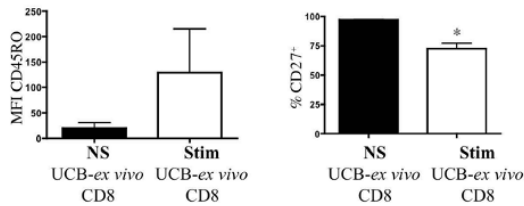

Figure 3 Characterization of activation marker status on activated CD8 ${ }^{+}$T cells generated in vitro. (A) Day 60-70 HSC/OP9-DL1 cOCulturederived CD8 SP T cells were purified as shown, $\mathrm{CD}^{+} \mathrm{CD}^{-}$and $\mathrm{CD}^{+}$, and stimulated anti-CD3/CD28 mAbs for 5 days. (B) Left-side panel displays flow cytometric analyses of cell size measured by Forward-light Scatter (FSC) intensity; right-side panel displays mean FSC for nonstimulated (NS) and stimulated (Stim) $\mathrm{CD}^{+} \mathrm{CD}^{+}$cells $(n=5 ; p=0.004$; t-test). (C) Flow cytometric analyses for the expression of CD45RO, CD27, CD38 and MHC-class II for stimulated (Stim) and non-stimulated (NS) CD8 ${ }^{+}$CD3 ${ }^{+}$cells (solid black line and shaded histograms, respectively). (D) Flow cytometric analyses for the expression of CD45RO, CD27, CD38 and MHC-class II for stimulated (Stim) and non-stimulated (NS) $\mathrm{CD}^{+} \mathrm{CD}^{+}$cells obtained from the UCB Lin ${ }^{+}$fraction. Analysis of CD45RO mean fluorescence intensity (MFI) and percentage of CD27 ${ }^{+}$cells for (E) HSC/OP9-DL1 coculture (in-vitro)-derived $\mathrm{CD}^{+} \mathrm{CD}^{+} \mathrm{T}$ cells and (F) UCB-ex vivo CD8 ${ }^{+} \mathrm{CD}^{+} \mathrm{T}$ cells were performed (MFI CD45RO in vitroderived, $\mathrm{p}=0.02 ; \mathrm{n}=3$; $\mathrm{t}$-test; \%CD27 ${ }^{+}$in vitro-derived, $\mathrm{p}=0.007 ; \mathrm{n}=3$; t-test; \%CD27 ${ }^{+}$UCB-ex vivo, $\mathrm{p}=0.03 ; \mathrm{n}=2 ; \mathrm{t}$-test). ${ }^{*}$ indicates statistical significance.

of mature T-lineage cells [24,25]. Nonetheless, we now provide clear evidence for the maturation of functionally responsive CD8 $\mathrm{T}$ cells generated from human $\mathrm{UCB}$ HSCs in coculture with OP9-DL1 cells.

Although some of the gene transcript levels were not identical to UCB-ex vivo CD8 T cells, this may be reflect the fact that coculture-derived $\mathrm{T}$ cells are more akin to human post-natal thymocytes, rather than $\mathrm{T}$ cells found within the periphery. In addition, some differences in cell surface expression may be due to different temporal kinetics of up/downregulation between in vitro-generated versus UCB-ex vivo CD8 T cells. Recently, van Coppernolle et al. reported the development of CD8 SP $\alpha \beta$ T cells and large numbers of $\gamma \delta \mathrm{T}$ cells following OP9-DL1 coculture from PNT. While $\gamma \delta \mathrm{T}$ cells can be detected in UCB-derived OP9-DL1 cocultures, we find them at very low frequencies (data not shown). This suggests that the CD $34^{+}$PNT, compared to UCB HSCs, have received instructive signals that are Notch independent, which appear to affect specific $\mathrm{T}$-lineage outcomes.
The observation that functionally mature CD8 SP Tlineage cells are generated from HSCs on OP9-DL1 stroma, raises the question of which cell-type, within the cultures, is mediating the MHC-dependent positive selection of this population. It is unlikely that the OP9 cells, which express mouse MHC class I, which is not effectively recognized by human CD8 molecules [26], would supply the required positive selection signals. Rather, a human MHC class I-expressing UCB-derived cell, which may or may not be a T-lineage cell, is likely to be the conveyor of these signals. Although van Coppernolle et al. describe the generation of mature CD8 T cells from postnatal thymocytes cocultured on OP9DL1, and excluded mouse MHC-I as a mode of selection due to its absence on OP9-DL1 cells, our analysis showed that OP9-DL1 cells are in fact MHC class Iexpressing cells (data not shown), suggesting that this possibility remains available for supporting CD8 positive selection. Indeed, the high transcript levels of Eomes, while low for PLZF, suggest that the in vitro-derived CD8 SP cells are likely conventional T-lineage cells and 


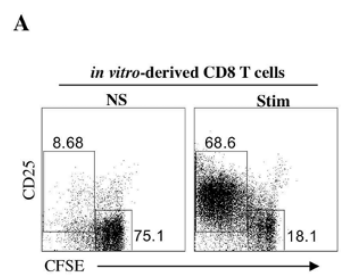

B

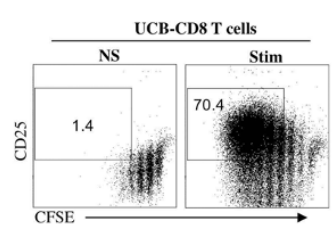

C

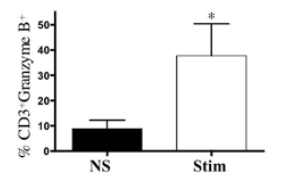

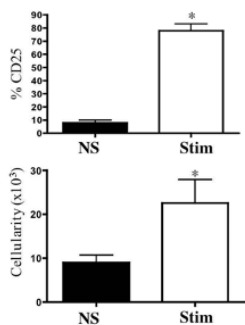
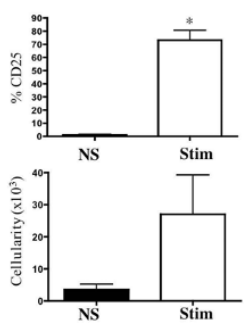

D

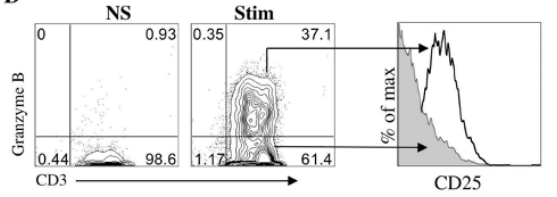

$\mathbf{E}$

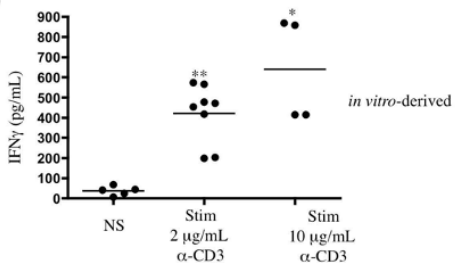

$\mathbf{F}$

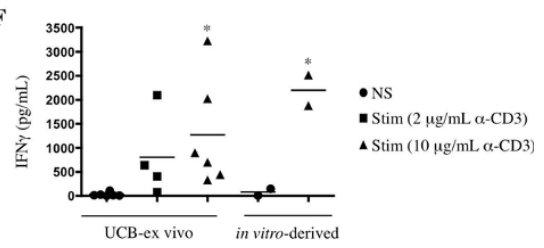

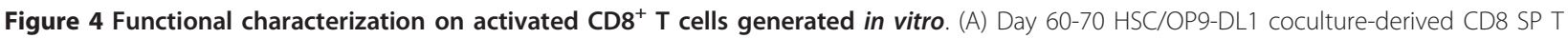
cells and (B) UCB-ex vivo CD8 T cells were purified and stimulated with anti-CD3/CD28 mAbs for 5 days. Flow cytometric analyses of CFSE levels and CD25 (left side), and percentage of $\mathrm{CD}_{2} 5^{+}$cells (upper right) and cellularity (lower right) for stimulated (Stim) versus non-stimulated (NS) are shown (* indicates $p<0.05$ ). (C) Analysis of the percentage of in vitro-derived CD8 ${ }^{+} \mathrm{CD}^{+}{ }^{+}$intracellular Granzyme- $\mathrm{B}^{+}$expressing cells for stimulated versus non-stimulated is shown $(p=0.02)$. ( $E-F)$ Human IFN $\gamma$ levels from culture supernatants derived from the above-outlined experiment were determined by ELISA. (E) Statistical significance was measured by unpaired t-test for stimulated and non-stimulated in vitroderived T cells. * $(p<0.005) 2 \mu \mathrm{g} / \mathrm{mL}$ anti-CD3/CD28 stimulated group versus non-stimulated. ${ }^{* *}(p<0.0005) 10 \mu \mathrm{g} / \mathrm{mL}$ anti-CD3/CD28 versus non-stimulated. Data are representative of at least 3 independent experiments, with the exception of the data from the $10 \mu \mathrm{g} / \mathrm{ml} \mathrm{stimulations,}$ which are derived from 2 independent experiments. (F) Statistical significance was measured by unpaired t-test for stimulated $(10 \mu \mathrm{g} / \mathrm{mL}) \mathrm{and}$ non-stimulated UCB-ex vivo T cells. ${ }^{*}(p<0.05)$. Data are representative of at least 4 independent UCB-ex vivo CD8 T cells. The data from the in vitro-generated T cells (non-stimulated and $10 \mu \mathrm{g} / \mathrm{mL}$ stimulation), are derived from 2 independent experiments.

not cells with innate-like function and phenotype, which are typically the product of T-to-T selection [27], such as NKT cells, $\gamma \delta$-T cells and innate CD8 T cells [28].

\section{Conclusions}

Taken together, our findings demonstrate that HSC/ OP9-DL1 cocultures produce functional CD8 SP T-cells, which are $\mathrm{CD}^{+} \mathrm{CD}^{2} 7^{+} \mathrm{CD} 1 \mathrm{a}^{-}$, and following TCR-stimulation up-regulate CD25, CD45RO, CD38 and MHC class II, while down-regulating CD27 expression. This complex phenotype is unique to activated human $\mathrm{T}$ cells $[29,30]$ and consistent with full effector maturation and effective cytolytic capability [31,32], as seen with the induced expression of Granzyme-B and IFN $\gamma$
A

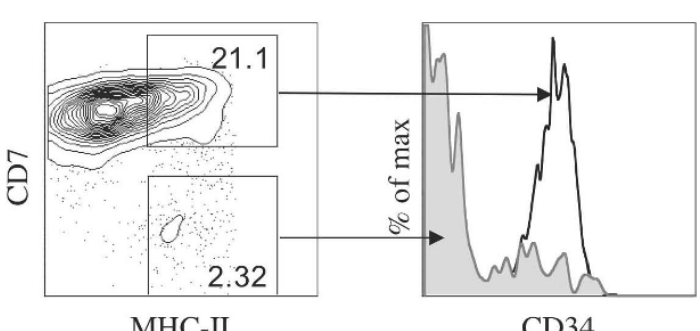

B

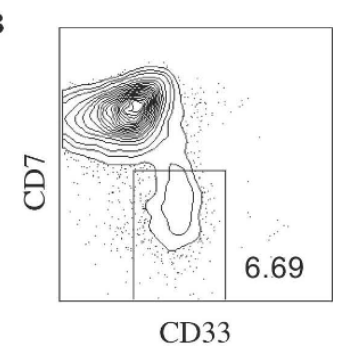

Figure 5 Characterization of MHC class II-expressing cells derived from OP9-DL1 culture. Flow cytometric analysis for cell surface expression of (A) MHC class II, CD7 (left side) and CD34 on MHC II CD7 ${ }^{+}$-gated cells (solid black line) and MHC $\|^{+}$CD7-gated cells (shaded histogram) from a day 40 HSC/OP9-DL1 coculture, and (B) CD33 and CD7 from a day 45 HSC/OP9-DL1 coculture. Numbers in plots indicate percentage of cells within each gate shown. Data are representative of at least 2 independent experiments. 


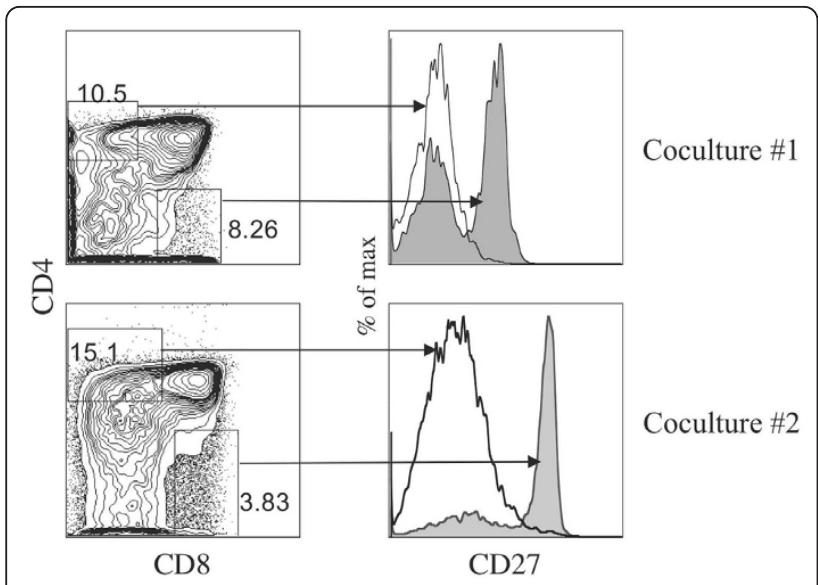

Figure 6 Characterization of single-positive T cells generated from HSC/OP9-DL1 coculture. Flow cytometric analysis for cell surface expression of CD4 and CD8 is presented for 2 independent cocultures (left side). CD27 expression was examined on CD4 $4^{+}$CD8gated cells (solid black line) and on $\mathrm{CD} 4^{-} \mathrm{CD} 8^{+}$-gated cells (shaded histogram).

by the in vitro-derived CD8 T-cells. The generation of functionally responsive $\mathrm{T}$ cells derived in vitro from HSCs may broaden the therapeutic avenue for treatment of immunodeficiency and adoptive immunotherapy.

\section{Methods}

\section{Umbilical cord blood samples}

Human umbilical cord blood (UCB) samples were obtained as previously described [8]. Briefly, within 24 hours of collection, cord blood mononuclear cells were isolated using Ficoll density centrifugation and then pre-enriched into lineage (Lin: CD2, CD3, CD14, CD16, CD19, CD24, CD56, CD66b, glycophorin A)negative $\left(\mathrm{Lin}^{-}\right)$and lineage-positive $\left(\mathrm{Lin}^{+}\right)$fractions with the autoMACS-pro cells sorter (Miltenyi Biotec, Auburn, CA) using the StemSep ${ }^{\mathbb{R}}$ human progenitor cell enrichment cocktail (Stem Cell technologies, Vancouver, $\mathrm{BC}$, Canada). To isolate the human HSCs, $\mathrm{Lin}^{-}$cells were stained with anti-human CD38-APC and antihuman CD34-FITC mAbs and sorted for $\mathrm{CD} 4^{+} \mathrm{CD} 38^{-1}$ lo cells utilizing a FACSAria cell sorter (BD Biosciences, San Jose, CA). Sorted human HSCs were greater than $99 \%$ pure as determined by post-sort analysis.

\section{Human HSC and OP9-DL1 cell coculture}

OP9-control or OP9-DL1 cells were generated and maintained in OP9-media as previously described [5]. Typically, 1-5 $\times 10^{4}$ sorted UCB HSCs (CD34+ CD38 $8^{-/ \mathrm{lo}}$ ) were added per individual well of a 6-well plate containing confluent OP9-DL1 cells, and the cultures were maintained as previously described [33].

\section{Flow Cytometry}

Fluorescein isothiocyanate (FITC)-, R-Phycoerythrin (PE)-, allophycocyanin (APC)-, PE-Cy7-, Alexa Fluor700 and eFluor $650 \mathrm{NC}$ antibodies were purchased commercially (BD Biosciences, San Jose, CA or eBioscience, San Diego, CA). FITC: anti-CD34, anti-HLA-DR/DP/ DQ (MHC-II), anti-CD3, anti-CD8; PE: anti-CD27, antiCD4, anti-CD7, anti-Granzyme B; APC: anti-CD1a, antiCD25, anti-CD38, anti-CD34; PE-Cy7: anti-CD8; Alexa Fluor-700: anti-CD4; eFluor 650NC: anti-CD3, antiCD45RO. Intracellular staining for Granzyme B was performed using the Cytofix/Cytoperm kit according to manufacturer's instructions (BD-Biosciences). Cell suspensions were FcRII-blocked and stained, and analyzed with a FACSCalibur (BD-Biosciences) or an LSR-II cytometer. Data analysis was performed using FlowJo software (Tree Star, Ashland, OR) by gating on live lymphocytes and lack of propidium iodide uptake. Numbers in quadrant corners represent percent of gated cells.

\section{T-cell stimulation assays}

UCB-ex vivo CD3/TCR- $\alpha \beta^{+} \mathrm{CD} 8^{+} \mathrm{T}$ cells or in vitrogenerated $\mathrm{CD} 3 / \mathrm{TCR}-\alpha \beta^{+} \mathrm{CD} 8^{+} \mathrm{SP}$ cells sorted from HSC/OP9-DL1 cocultures at days 60-70, and $4 \times 10^{4}$ cells were seeded in individual wells of a flat bottom 96well plate coated with or without anti-CD3 [Clone UCHT1] ( 2 or $10 \mu \mathrm{g} / \mathrm{mL})$ and soluble anti-CD28 [Clone CD28.2] $(1 \mu \mathrm{g} / \mathrm{mL})$ mAbs. All wells contained OP9media supplemented with rhIL-2 $(1 \mathrm{ng} / \mathrm{mL})$ and rhIL-7 (1 ng/mL) (Peprotech, Rocky Hill, NJ or R\&D Systems, Minneapolis, MN) cytokines and were analyzed after 5 days. For T-cell proliferation assays, $4 \times 10^{4}$ in vitrogenerated $\mathrm{CD}^{+} \mathrm{CD}^{+} \mathrm{T}$-cells were sorted and loaded with $10 \mu \mathrm{M}$ carboxyfluorescein succinimidyl ester (CFSE) according to manufacturer's protocol (Molecular Probes, Eugene, OR) prior to plating. Loss of CFSE labeling was assayed after 5 days of stimulation using a FACSCalibur cytometer or an LSRII cytometer.

\section{Quantitative real-time reverse-transcriptase polymerase chain reaction (QRT-PCR)}

Total RNA was isolated in Trizol-reagent and reverse transcribed using Superscript-III and Oligo $(\mathrm{dT})_{12-18}$ primers (Invitrogen, Burlington, ON). Diluted cDNA samples from sorted coculture-derived $\mathrm{CD}^{+}$and from the $\mathrm{UCB} \mathrm{Lin}^{+}$fraction that was sorted for $\mathrm{CD} 4^{-} \mathrm{CD}^{+} \mathrm{CD}^{+}$ $\mathrm{T}$ cells, $\mathrm{CD} 4^{+} \mathrm{CD}^{-} \mathrm{CD}^{+} \mathrm{T}$ cells and $\mathrm{CD} 33^{+}$cells were used as templates for QRT-PCR reactions. Detection of the QRT-PCR was performed with the SYBR Green PCR master mix according to manufacturer's instructions (Qiagen, Mississauga, ON or Bio-Rad, Hercules 
CA) on the Applied Biosystems Sequence Detection System 7000 (Life Technologies, Carlsbad, CA). All transcript levels were normalized to human $\beta$-actin. Gene-specific forward $(\mathrm{F})$ and reverse $(\mathrm{R})$ primers are as follows: PLZF, (F) AGTGAGTGCAACCGCACCTT and (R) GGAAGCAGCTGCCACAGAAC; Eomes, (F) ATGCAGGGCAACAAAATGTATG and (R) GTCTCATCCAGTGGGAACCAGTA; Th-Pok, (F) GCCTGGACA GCCAAGACAAG and (R) AAGGGCTTCTCGCCTG TGT; Gata-3, (F) GATGGCACGGGACACTACCT and (R) GCTCTCCTGGCTGCAGACA;

\section{Acknowledgements}

We are grateful to Gisele Knowles and Arian Khandani for their expert assistance with flow cytometric cell sorting, Roxanne Holmes and John Xu for technical support, Dr. Rose Kung and the staff of the Perinatal and Gynecology Program of Women's College Hospital and Sunnybrook Health Sciences Centre for their ongoing support in providing material for our research.

This work was supported by grants to JCZP from the Canadian Institutes of Health Research (CIHR) HOP-83070, The Terry Fox Foundation, The Ontario HIV Treatment Network (OHTN), and The Krembil Foundation; JCZP is supported by a Canada Research Chair in Developmental Immunology.

\section{Author details}

'Department of Immunology, University of Toronto, and Sunnybrook Research Institute, 2075 Bayview Avenue, Toronto, Ontario M4N 3M5, Canada. ${ }^{2}$ Sunnybrook Health Sciences Centre, Women \& Babies Program, 2075 Bayview Avenue, Toronto, Ontario M4N 3M5, Canada.

\section{Authors' contributions}

GA performed and designed the research, analyzed data, and wrote paper. EH contributed vital reagents. RNLMM performed research. JCZP designed the research, and wrote the paper. All authors read and approved the final manuscript.

Received: 9 September 2010 Accepted: 23 March 2011

Published: 23 March 2011

\section{References}

1. Spits H: Development of alphabeta T cells in the human thymus. Nat Rev Immunol 2002, 2:760-772.

2. Storek J, Gooley T, Witherspoon RP, Sullivan KM, Storb R: Infectious morbidity in long-term survivors of allogeneic marrow transplantation is associated with low CD4 T cell counts. Am J Hematol 1997, 54:131-138.

3. Douek DC, Vescio RA, Betts MR, Brenchley JM, Hill BJ, Zhang L, Berenson JR, Collins RH, Koup RA: Assessment of thymic output in adults after haematopoietic stem-cell transplantation and prediction of T-cell reconstitution. Lancet 2000, 355:1875-1881.

4. van den Brink MR, Alpdogan O, Boyd RL: Strategies to enhance T-cell reconstitution in immunocompromised patients. Nat Rev Immunol 2004, 4:856-867.

5. Schmitt TM, Zúñiga-Pflücker JC: Induction of T cell development from hematopoietic progenitor cells by delta-like-1 in vitro. Immunity 2002, 17:749-756.

6. Schmitt TM, de Pooter RF, Gronski MA, Cho SK, Ohashi PS, ZúñigaPflücker JC: Induction of T cell development and establishment of T cell competence from embryonic stem cells differentiated in vitro. Nat Immunol 2004, 5:410-417.

7. La Motte-Mohs RN, Herer E, Zúñiga-Pflücker JC: Induction of T-cell development from human cord blood hematopoietic stem cells by Delta-like 1 in vitro. Blood 2005, 105:1431-1439.

8. Awong G, Herer E, Surh CD, Dick JE, La Motte-Mohs RN, Zuniga-Pflucker JC: Characterization in vitro and engraftment potential in vivo of human progenitor T cells generated from hematopoietic stem cells. Blood 2009, 114:972-982
9. De Smedt M, Hoebeke I, Plum J: Human bone marrow CD34+ progenitor cells mature to T cells on OP9-DL1 stromal cell line without thymus microenvironment. Blood Cells Mol Dis 2004, 33:227-232.

10. Zakrzewski JL, Kochman AA, Lu SX, Terwey TH, Kim TD, Hubbard VM, Muriglan SJ, Suh D, Smith OM, Grubin J, et al: Adoptive transfer of T-cell precursors enhances T-cell reconstitution after allogeneic hematopoietic stem cell transplantation. Nat Med 2006, 12:1039-1047.

11. Van Coppernolle S, Verstichel G, Timmermans F, Velghe I, Vermijlen D, De Smedt M, Leclerca G, Plum J, Taghon T, Vandekerckhove B, Kerre T: Functionally mature CD4 and CD8 TCRalphabeta cells are generated in OP9-DL1 cultures from human CD34+ hematopoietic cells. J Immunol 2009, 183:4859-4870.

12. Zhao Y, Parkhurst MR, Zheng Z, Cohen CJ, Riley JP, Gattinoni L, Restifo NP, Rosenberg SA, Morgan RA: Extrathymic generation of tumor-specific $T$ cells from genetically engineered human hematopoietic stem cells via Notch signaling. Cancer Res 2007, 67:2425-2429.

13. van Lent AU, Nagasawa M, van Loenen MM, Schotte R, Schumacher TN, Heemskerk MH, Spits $\mathrm{H}$, Legrand N: Functional human antigen-specific T cells produced in vitro using retroviral T cell receptor transfer into hematopoietic progenitors. J Immunol 2007, 179:4959-4968.

14. Res $\mathrm{P}$, Spits $\mathrm{H}$ : Developmental stages in the human thymus. Semin Immunol 1999, 11:39-46.

15. Vanhecke D, Leclercq G, Plum J, Vandekerckhove B: Characterization of distinct stages during the differentiation of human $C D 69+C D 3+$ thymocytes and identification of thymic emigrants. J Immunol 1995, 155:1862-1872.

16. Res $P$, Blom B, Hori T, Weijer K, Spits H: Downregulation of CD1 marks acquisition of functional maturation of human thymocytes and defines a control point in late stages of human T cell development. J Exp Med 1997, 185:141-151.

17. He X, Park K, Wang H, Zhang Y, Hua X, Li Y, Kappes DJ: CD4-CD8 lineage commitment is regulated by a silencer element at the ThPOK transcription-factor locus. Immunity 2008, 28:346-358.

18. Pearce EL, Mullen AC, Martins GA, Krawczyk CM, Hutchins AS, Zediak VP, Banica M, DiCioccio CB, Gross DA, Mao CA, et al: Control of effector CD8+ T cell function by the transcription factor Eomesodermin. Science 2003, 302:1041-1043.

19. Narayanan $S$, Silva R, Peruzzi G, Alvarez Y, Simhadri VR, Debell $K$, Coligan JE, Borrego F: Human Th1 cells that express CD300a are polyfunctional and after stimulation up-regulate the T-box transcription factor eomesodermin. PLoS One 2010, 5:e10636.

20. Savage AK, Constantinides MG, Han J, Picard D, Martin E, Li B, Lantz O, Bendelac A: The transcription factor PLZF directs the effector program of the NKT cell lineage. Immunity 2008, 29:391-403.

21. Rosenberg SA, Restifo NP, Yang JC, Morgan RA, Dudley ME: Adoptive cell transfer: a clinical path to effective cancer immunotherapy. Nat Rev Cancer 2008, 8:299-308.

22. June CH: Principles of adoptive T cell cancer therapy. J Clin Invest 2007, 117:1204-1212

23. Kim JV, Latouche JB, Riviere I, Sadelain M: The ABCs of artificial antigen presentation. Nat Biotechnol 2004, 22:403-410

24. Delaney C, Heimfeld S, Brashem-Stein C, Voorhies H, Manger RL, Bernstein ID: Notch-mediated expansion of human cord blood progenitor cells capable of rapid myeloid reconstitution. Nat Med 2010, 16:232-236.

25. Watts KL, Delaney C, Humphries RK, Bernstein ID, Kiem HP: Combination of HOXB4 and Delta-1 ligand improves expansion of cord blood cells. Blood 116:5859-5866.

26. Irwin MJ, Heath WR, Sherman LA: Species-restricted interactions between CD8 and the alpha 3 domain of class I influence the magnitude of the xenogeneic response. J Exp Med 1989, 170:1091-1101.

27. Schwartzberg PL, Mueller KL, Qi H, Cannons JL: SLAM receptors and SAP influence lymphocyte interactions, development and function. Nat Rev Immunol 2009, 9:39-46.

28. Alonzo ES, Gottschalk RA, Das J, Egawa T, Hobbs RM, Pandolfi PP, Pereira P, Nichols KE, Koretzky GA, Jordan MS, Sant'Angelo DB: Development of promyelocytic zinc finger and ThPOK-expressing innate gamma delta $\mathrm{T}$ cells is controlled by strength of TCR signaling and Id3. J Immunol 184:1268-1279.

29. Ko HS, Fu SM, Winchester RJ, Yu DT, Kunkel HG: la determinants on stimulated human T lymphocytes. Occurrence on mitogen- and antigenactivated T cells. J Exp Med 1979, 150:246-255. 
30. Holling TM, van der Stoep N, Quinten E, van den Elsen PJ: Activated human T cells accomplish MHC class II expression through T cell-specific occupation of class II transactivator promoter III. J Immunol 2002, 168:763-770.

31. van Baarle $D$, Kostense $S$, van Oers MH, Hamann D, Miedema F: Failing immune control as a result of impaired CD8+ T-cell maturation: CD27 might provide a clue. Trends Immunol 2002, 23:586-591.

32. Hamann D, Baars PA, Rep MH, Hooibrink B, Kerkhof-Garde SR, Klein MR, van Lier RA: Phenotypic and functional separation of memory and effector human CD8+ T cells. J Exp Med 1997, 186:1407-1418.

33. Awong G, Motte-Mohs RN, Zúñiga-Pflücker JC: In vitro human T cell development directed by notch-ligand interactions. Methods Mol Biol 2008, 430:135-142

doi:10.1186/1471-2172-12-22

Cite this article as: Awong et al: Human CD8 T cells generated in vitro from hematopoietic stem cells are functionally mature. BMC Immunology 2011 12:22.

\section{Submit your next manuscript to BioMed Central} and take full advantage of:

- Convenient online submission

- Thorough peer review

- No space constraints or color figure charges

- Immediate publication on acceptance

- Inclusion in PubMed, CAS, Scopus and Google Scholar

- Research which is freely available for redistribution

Submit your manuscript at www.biomedcentral.com/submit
C Biomed Central 